\title{
CYTOGENETICS OF TWO SYMPATRIC Corydoras SPECIES (PISCES, SILURIFORMES, CHALLICHTYIDAE) OF SOUTHERN BRAZIL
}

\author{
ARTONI, R. F. ${ }^{1}$, TERÊNCIO, M. L. ${ }^{1}$, VICARI, M. R. ${ }^{2}$, MATIELLO, M. C. A. ${ }^{1}$, \\ CESTARI, M. M. ${ }^{3}$ and BERTOLLO, L. A. C. ${ }^{2}$ \\ ${ }^{1}$ Departamento de Biologia Estrutural, Molecular e Genética, Campus de Uvaranas, \\ Universidade Estadual de Ponta Grossa, CEP 84030-900, Ponta Grossa, PR, Brazil \\ ${ }^{2}$ Programa de Pós-Graduação em Genética e Evolução, Universidade Federal de São Carlos, \\ CEP 13565-905, São Carlos, SP, Brazil \\ ${ }^{3}$ Departamento de Genética, Centro Politécnico, Universidade Federal do Paraná, \\ CEP 81531-990, Curitiba, PR, Brazil \\ Corespondece to: Roberto Ferreira Artoni, Departamento de Biologia Estrutural, Molecular e Genética, \\ Universidade Estadual de Ponta Grossa, Campus de Uvaranas, CEP 84030-900, \\ Ponta Grossa, PR, Brazil, e-mail: rfartoni@uepg.br
}

Received February 2, 2004 - Accepted April 6, 2004 - Distributed February 28, 2006

(With 3 figures)

\begin{abstract}
Karyotypic data are presented for two sympatric Corydoras species of the Lagoa Dourada, namely, C. ehrhadti and C. paleatus, which are found in the upper Tibagi river basin (Ponta Grossa, State of Paraná, Brazil). The same diploid number and karyotypic formula were observed in both species/populations. A great similarity in the constitutive heterochromatin distribution and in the activity of nucleolar organizer regions was also found. The use of in situ hybridization with a fluorescent $18 \mathrm{~S}$ rDNA probe allowed for the identification of the species/populations through the location of ribosomal sites.
\end{abstract}

Keywords: karyotype, sympatry, heterochromatin, NORs, rDNA.

\section{RESUMO}

\section{Citogenética de espécies simpátricas de Corydoras (pisces, siluriformes, challichtyidae) do Sul do Brasil}

Dados cariotípicos são apresentados para duas espécies simpátricas de Corydoras da Lagoa Dourada, C. ehrhadti e C. paleatus, pertencentes à bacia do alto Rio Tibagi (Ponta Grossa, Paraná, Brasil). O mesmo número diplóide e fórmula cariotípica foram observados em ambas espécies/populações. Grande similaridade foi verificada também para a distribuição da heterocromatina constitutiva e atividade das regiões organizadoras de nucléolos. O emprego da hibridação in situ com sonda fluorescente de DNAr 18S possibilitou identificar as espécies/populações por meio da localização dos sítios ribossomais.

Palavras-chave: cariótipo, simpatria, heterocromatina, RONs, DNAr. 


\section{INTRODUCTION}

The genus Corydoras (Callichthyidae) is widespread throughout South America, comprising approximately 142 recognized species (Reis, 1998). According to Oliveira et al. (1992), this genus encompasses five natural groups of species that present karyotypic and DNA content similarities. Vicariance events such as those that occurred in the costal basin are mechanisms that help explain the high interspecific diversity in this group (Weitzman et al., 1988).

Karyotypic data and DNA content suggest an intense polyploidization process in the diversification and evolutionary history of this group (Oliveira et al., 1993a, b). The diploid chromosome number varies from $2 \mathrm{n}=40$ in $C$. natterei (Oliveira et al., 1990) to $2 \mathrm{n}=134$ in C. aeneus (Turner et al., 1992), while the nuclear DNA content varies from $1.04 \pm 0.09 \mathrm{pg}$ in $C$. cf. simulatus to $8.75 \pm 1.50 \mathrm{pg}$ in C. metae (Oliveira et al., 1992).
In the present study, we investigated the karyotypic structure of C. ehrhardti and C. paleatus in a sympatric zone, especially in relation to the presence and location of the $18 \mathrm{~S}$ rDNA.

\section{MATERIALS AND METHODS}

The two species of fishes belonging to the genus Corydoras, C. ehrhardti and C. paleatus, found in the upper Tibagi river basin (Lagoa Dourada, Vila Velha State Park, Ponta Grossa, State of Paraná, Brazil, $50^{\circ} 03^{\prime} \mathrm{W}, 25^{\circ} 14^{\prime} \mathrm{S}$ ) were cytogenetically studied (Fig. 1). Figs. $2 \mathrm{~g}$ and $2 \mathrm{~h}$ depicts the specimens of analyzed Corydoras species.

Nine males and 10 females of $C$. ehrhardti and 12 males and 8 females of $C$. paleatus were subjected to karyotypic analyses. Chromosomal preparations were obtained by the "air drying" method (Bertollo et al., 1978). Constitutive heterochromatin was verified according to the

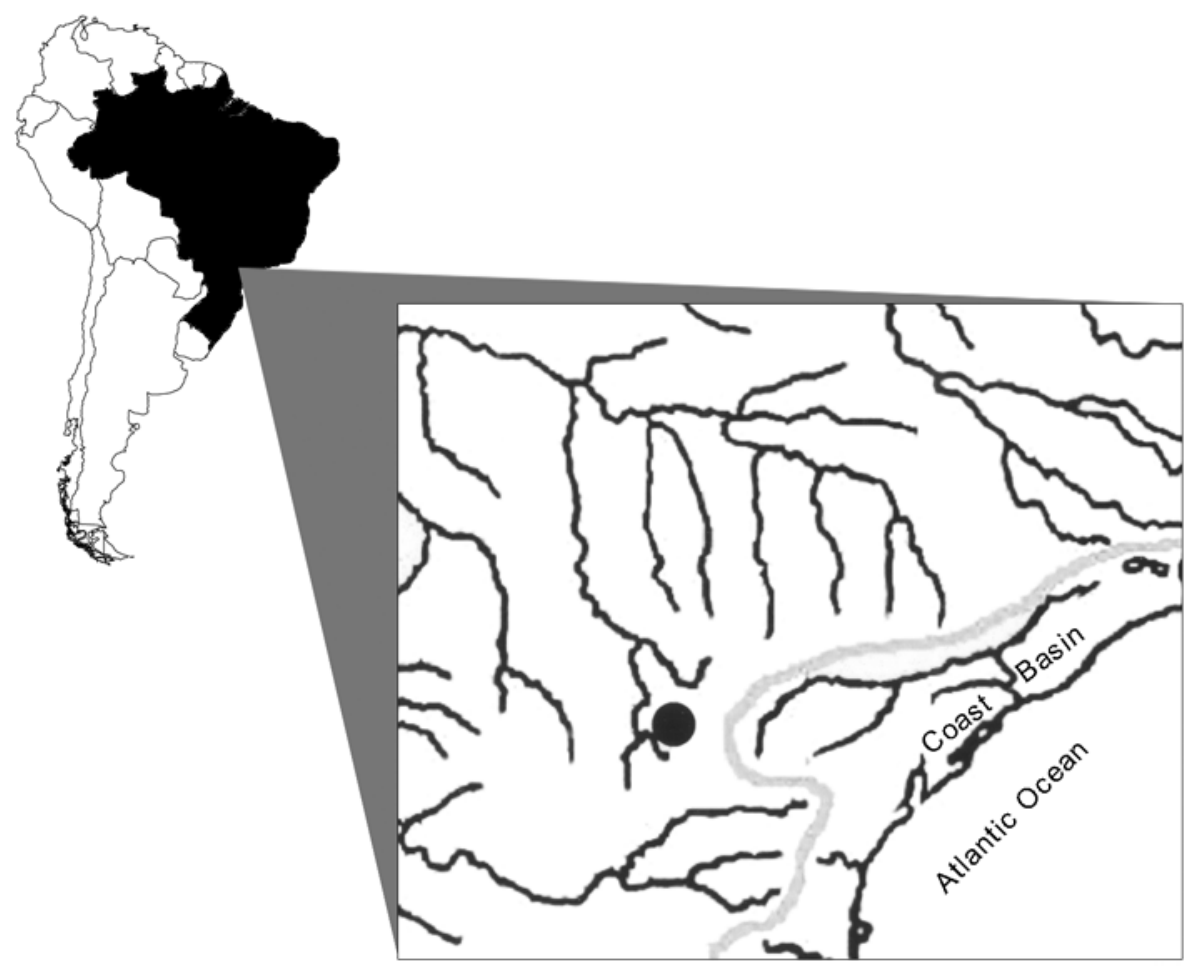

Fig. 1 - Map of South America showing the collection sites in detail. Coastal and continental rivers are separated by an imaginary line (gray line in the figure). The C. ehrhardti and C. paleatus collection sites in the region of the upper Tibagi river (Lagoa Dourada, Ponta Grossa, Paraná, Brazil). 
TABLE 1

Chromosomal data obtained for Corydoras species in sympatric condition

\begin{tabular}{|c|c|c|c|c|c|c|c|c|c|}
\hline \multirow[t]{2}{*}{ Species } & \multirow[t]{2}{*}{ Locality } & \multirow{2}{*}{$\begin{array}{c}\text { Number of } \\
\text { specimens } \\
\text { m/f }\end{array}$} & \multirow[t]{2}{*}{$2 n$} & \multicolumn{4}{|c|}{ Karyotype } & \multirow[t]{2}{*}{ NF } & \multirow{2}{*}{$\begin{array}{c}\text { Chrom. with } \\
\text { Ag-NORs / 18S rDNA }\end{array}$} \\
\hline & & & & $\mathbf{M}$ & SM & ST & $\mathbf{A}$ & & \\
\hline C. ehrhardti & $\begin{array}{l}\text { L. Dourada. } \\
\text { Ponta Grossa, PR, } \\
\text { Brazil }\end{array}$ & $9 / 10$ & 44 & 18 & 26 & 0 & 0 & 88 & $1 \mathrm{M} / 1 \mathrm{M} ; 1 \mathrm{SM}$ \\
\hline C. paleatus & $\begin{array}{l}\text { L. Dourada. } \\
\text { Ponta Grossa, PR, } \\
\text { Brazil }\end{array}$ & $12 / 8$ & 44 & 18 & 26 & 0 & 0 & 88 & $1 \mathrm{M} / 1 \mathrm{M}$ \\
\hline
\end{tabular}

$\mathrm{m}=$ male; $\mathrm{f}=$ female; $2 \mathrm{n}=$ diploid number; $\mathrm{M}=$ metacentric; $\mathrm{SM}=$ submetacentric; $\mathrm{ST}=$ subtelocentric;

$\mathrm{A}=$ acrocentric $; \mathrm{NF}=$ chromosome arm number; $\mathrm{Ag}-\mathrm{NORs}=$ nucleolar organizer regions; and 18S rDNA $=$ in situ hybridization with rDNA $18 \mathrm{~S}$.

procedure described by Sumner (1972) and nucleolar organizer regions were detected by means of silver nitrate (Ag-NORs), according to Howell \& Black (1980).

Fluorescent in situ hybridization (FISH) was used, following the procedure described by Pinkel et al. (1986) for rDNA mapping of the chromosomes. An $18 \mathrm{~S}$ rDNA probe was used, which was obtained by PCR from nuclear DNA of Prochilodus affinis, using the primers NS1 5' - GTAGTCATATGCTTGTCTC - 3' and NS8 5' - TCCGCAGGTTCACCTACGGA - 3' (White et al., 1990). The probe was labeled with 16-dATP biotin by nick translation, according to the manufacturer's specifications (Bionick Labeling System - Gibco BRL). The metaphase chromosomes were treated with RNAse $(40 \mu \mathrm{g} / \mathrm{mL}$ in $2 \times \mathrm{SSC}$ ) at $37{ }^{\circ} \mathrm{C}$ for $1 \mathrm{~h}$ and with pepsin $(0.005 \%$ in $10 \mathrm{mM} \mathrm{HCl})$ at $37^{\circ} \mathrm{C}$ for $10 \mathrm{~min}$, after which they were denatured in formamide $/ 2 \times \mathrm{SSC}$ $70 \%$ for $5 \mathrm{~min}$. The hybridization solution was composed of formamide $50 \%, 2 \times$ SSC, dextran sulfate $(10 \%)$ and denatured probe. After overnight hybridization at $37{ }^{\circ} \mathrm{C}$, the slides were washed in formamide $50 \%$ at $42{ }^{\circ} \mathrm{C}$ for $20 \mathrm{~min}$ and $0.1 \times \mathrm{SSC}$ at $60{ }^{\circ} \mathrm{C}$ for $15 \mathrm{~min}$. The hybridization signals were detected by using conjugated avidin-fluorescein (FITC) and biotinilated anti-avidin antibody. The chromosomes were counterstained with propidium iodide $(50 \mu \mathrm{g} / \mathrm{mL})$ and analyzed in an Olympus BX 50 epifluorescence microscope. The images of the chromosomal plates were captured using the software CoolSNAP-pro (Media Cybernetics).
The chromosomes were organized in metacentric (M) and submetacentric (SM), in decreasing order of size according to the arms relation (Levan et al., 1964). The NF (chromosome arm number) was determined considering M/SM chromosomes having two arms and ST/A chromosomes having one arm, according to Oliveira et al. (1993a).

\section{RESULTS}

The Corydoras species analyzed here (C. ehrhardti and C. paleatus) presented $2 \mathrm{n}=4$ chromosomes with a fundamental number (FN) of 88 and a karyotypic formula composed of 9 metacentric chromosome pairs and 13 submetacentric chromosome pairs (Table 1). The first metacentric chromosome pair stands out for presenting much larger chromosomal elements than the other metacentric pairs. The karyotypes were homomorphic, with an absence of morphologically differentiated sex chromosomes in both species (Figs. 2a and 2d).

The constitutive heterochromatin was distributed in large heterochromatic blocks in the pericentromeric region in homologous chromosomes between the two species, markedly in metacentric pair number 2 and in submetacentric pairs 10 and 13 (Figs. 2c and 2f). The silver-stained nucleolar organizer regions (Ag-NORs) were evident in a single metacentric pair in a terminal position of the long arm in C. ehrhardti and $C$. paleatus (Figs. 2b and 2e). 


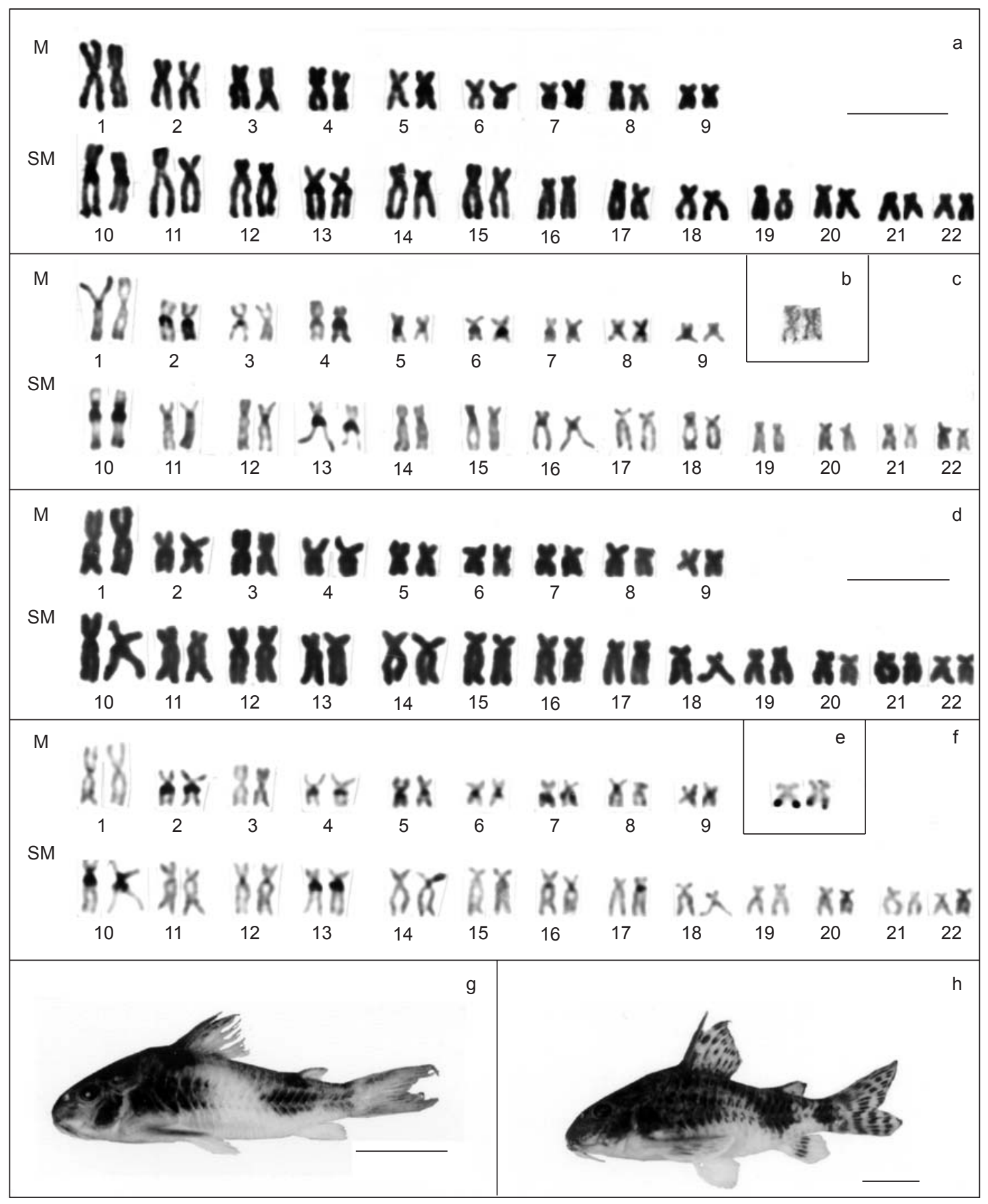

Fig. 2 - Karyotypes, chromosomes and specimens of Corydoras ehrhardti (a, c, b, g) and Corydoras paleatus (d, f, e, h), respectively. (a, d) show karyotypes by Giemsa staining, while $(c, f)$ present the constitutive heterochromatin distribution pattern evidenced by the C-band. (b and e) highlight the NOR chromosomes stained with silver nitrate. ( $\mathrm{g}$ and $\mathrm{h}$ ) show Corydoras ehrhardti and Corydoras paleatus specimens, respectively. Bars: $10 \mu \mathrm{m}$ (Karyotypes) and $10 \mathrm{~mm}$ (Specimens). 
The 18S rDNA fluorescent in situ hybridization confirmed the presence of these gene loci in a medium-sized metacentric pair, in a terminal position of the long arm comparable in both species studied here. Additionally, C. paleatus displayed a small submetacendtric chromosome marked in the long arm (Fig. 3). A difference was found in the size of the ribosomal cistrons in the medium-sized metacentric pair between the two species, with $C$. paleatus presenting visibly larger cistrons.

\section{DISCUSSION}

According to Oliveira et al. (1992), Corydoras comprises five groups of species presenting similar karyotypic and DNA content. C. ehrhardti and C. paleatus belong to the same karyotypic group, which occurs in the southeastern coastal region of Brazil (Oliveira et al., 1993a). When found in the coastal zone, the sympatric occurrence of Corydoras species always points to the presence of species belonging to distinct karyotypic groups, possibly as a result of polyphyletic evolution (Oliveira et al., op. cit.).

This paper offers the first description of the sympatric occurrence of two Corydoras species belonging to the same karyotypic group. In the region of Ponta Grossa (Paraná, Brazil) where the $C$. ehrhadti and $C$. paleatus specimens were collected, the Lagoa Dourada is part of the Tibagi river basin, located in the second plateau of the State of Paraná in the continental interior. Therefore, in the case of Corydoras, the special conditions of vicariance and costal species distribution proposed by Weitzman et al. (1988) must be considered only for the coastal region, whereas in the continental interior, the current species distribution should represent more complex historical speciation events and biogeography, especially considering that $C$. ehrhadti does not engage in reproduction migration, while $C$. paleatus migrates short distances (Winemiller, 1989; Burgess, 1989).

Our karyotypic analysis of $C$. ehrhadti and C. paleatus from the upper Tibagi river region (Ponta Grossa, Paraná State, Brazil) revealed considerable similarities of the karyotypic macrostructure (18M + 26SM, Fig. 2) with other populations of this species. However, slight alterations in the karyotypic formula should be treated as a consequence of chromosome pairing adjustment and/or allopatric speciation processes. On the other hand, this evidence does not interfere with our conclusion that these species probably make up a monophyletic branch with a common ancestor in the genus.

The distribution of constitutive heterochromatin is a powerful populational marker for these species. The $C$. ehrhardti and C.paleatus
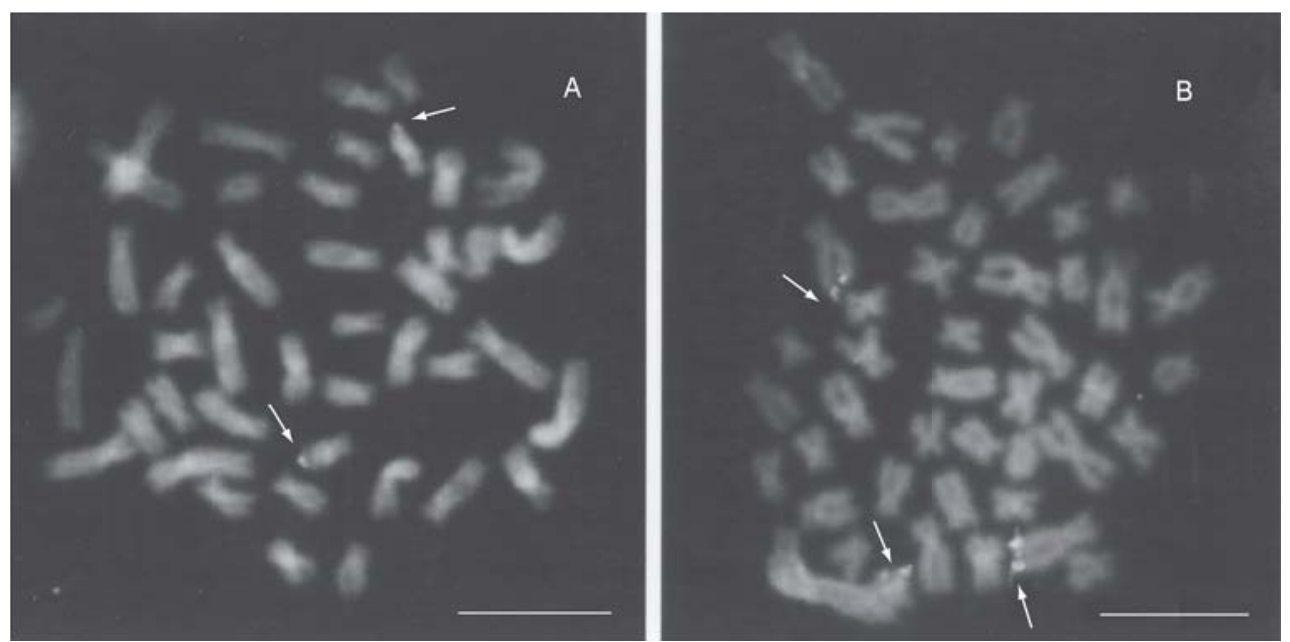

Fig. 3 - (A) Corydoras ehrhardti and (B) Corydoras paleatus mitotic chromosomes subjected to in situ hybridization with $18 \mathrm{~S}$ rDNA probe. The arrows indicate the location of the nucleolar organizing region in the two species. Bars: $10 \mu \mathrm{m}$. 
populations analyzed in this study present conspicuous heterochromatic pericentromeric bands in comparable chromosomes, as verified in pairs number 2 (metacentric), 10 and 13 (submetacentrics) (Figs. 2c and 2f). In other cases, these bands are highly variable, as in the C. paleatus populations studied by Oliveira et al. (1993a). In the population of the Curitiba region (State of Paraná, Brazil), the heterochromatin appeared in small blocks but was more distributed among the chromosomes of the karyotypic complement, while in the population of Rio Grande (State of Rio Grande do Sul, Brazil), the heterochromatin was found in large heterochromatic blocks, albeit restricted to fewer chromosomes (Oliveira et al., op. cit.).

In this study, contrary to expectation, the $C$.paleatus population presented a similar karyotype to the one found by Oliveira et al. (1993a) for the $C$. paleatus population of Rio Grande do Sul, differentiated from the Curitiba population, which is geographically closer to the population under study (Lagoa Dourada, city of Ponta Grossa, upper Tibagi river region). Although the C. paletus population of the Dourada Lagoon is more similar to the Rio Grande population, these populations also display minor karyotypic differences, especially in their karyotypic formula (Rio Grande = $22 \mathrm{M}+$ 22SM; Ponta Grossa $=18 \mathrm{M}+26 \mathrm{SM}$ ). Since the fundamental number remains the same $(\mathrm{FN}=88)$, this karyotypic diversification may be attributed to non-Robertsonian chromosome rearrangements. This is yet another indication reinforcing the notion of fixation of chromosome rearrangements in isolated populations, as has been recorded for other Neotropical fish species such as Hoplias malabaricus (Bertollo et al., 2000) and Astyanax scabripinnis (Moreira Filho \& Bertollo, 1991).

The C-banding in C. ehrhadti also provides interesting information. The population analyzed here and the one from Jaraguá do Sul (State of Santa Catarina, Brazil) studied by Oliveira et al. (1993a) showed clear differences with regard to the karyotypic distribution of the constitutive heterochromatin. While the first submetacentric pair appears with large heterochromatic blocks in the population of this study, the Jaraguá do Sul population presents no such markings in this chromosome pair.
More consistent differences between the karyotypes of the Corydoras species analyzed here and those studied by Oliveira et al. (1993a) can be pointed out regarding the presence and activity of the nucleolar organizer regions (NORs). In their analyses, Oliveira et al.(op. cit.) found silver-stained NORs varying from one to two pairs in C. ehrhadti and from one to three pairs in C.paleatus. In the present work, comparable Ag-NORs were evident in only one metacentric chromosome pair in both $C$. ehrhardti and C.paleatus, which were prominent in the terminal region of the long arm (Figs. 2b and 2e). This indicates that these populations do not possess multiple Ag-NORs or at least that they were not active in the preceding interphase. Much heterogeneity has been observed in the detection of NOR numbers and sizes in fish. Especially among the siluriforms, cases of simple NORs (one pair only) have been recorded, as well as in some Pimelodidae (Dias \& Foresti, 1993; Fenocchio, 1993; Fenocchio \& Bertollo, 1992a), Ageneiosidae (Fenocchio \& Bertollo, 1992b) and in Doradidae species (Fenocchio et al., 1993). On the other hand, a few cases are more heterogeneous, with species presenting one or more NOR pairs (multiple NORs), as in the case of some Callichythiidae (Oliveira et al., 1988; Oliveira, 1991; Porto \& Feldberg, 1992) and Loricariidae species (Artoni \& Bertollo, 2001).

Adding to the results obtained through silver staining to reveal the activity of the nucleolar organizer regions in the two Corydoras species studied here, fluorescent in situ hybridization (FISH) with an $18 \mathrm{~S}$ rDNA probe evidenced the presence of multiple NOR sites in C. paleatus, contrary to $C$. ehrhadti, which presented only one chromosome pair with a hybridization signal (Fig. 3). This is the most consistent diagnostic karyotypic evidence resulting from the analysis of the sympatric species $C$. ehrhardti and $C$. paleatus of the upper Tibagi river.

FISH with rDNA probes has helped detect the presence of inactive NORs in fish chromosomes in different cases, such as in the association of NORs and sex chromosomes (Artoni \& Bertollo, 2002) and in cases of multiple silent loci (Centofante et al., 2003).

The considerable variation in NOR number and position observed among species and populations of Corydoras indicates that more 
detailed studies are extremely important for the karyotypic analysis and description of the species, due to the possible phenotypic effects and adaptive values resulting from this variability.

The slight karyotypic divergence established between the two analyzed species confirms the high degree of kinship they share. However, the fixation of structural polymorphisms and of gene activity point to the accumulation of slight karyotypic differences between the populations analyzed here and those described in the literature, so that the former do not seem to form interspecific hybrids when found in sympatry.

Acknowledgments - The authors are indebted to Dr. O. MoreiraFilho for his technical support and for the use of the facilities for the FISH procedures. Thanks are also due to IAP (Instituto Ambiental do Paraná), IBAMA (Instituto Brasileiro do Meio Ambiente), and Paranaturismo for granting a permit to capture fish in the Vila Velha State Park), and to Fundação Araucária (Fundação Araucária de Apoio ao Desenvolvimento Científico e Tecnológico do Estado do Paraná) and CNPq (Conselho Nacional de Desenvolvimento Científico e Tecnológico) (Brazil) for their financial support.

\section{REFERENCES}

ARTONI, R. F. \& BERTOLLO, L. A. C., 2001, Trends in the Karyotype evolution of Loricariidae fish (Siluriformes). Hereditas, 134: 201-210.

ARTONI, R. F. \& BERTOLLO, L. A. C., 2002, Evolutionary aspects of the ZZ/ZW sex chromosome system in the Characidae fish, genus Triportheus. A monophyletic State and NOR. Heredity, 89: 15-19.

BERTOllo, L. A. C., BORN, G. G., DERGAM, J. A., FENOCCHIO, A. S. \& MOREIRA-FILHO, O., 2000, A biodiversity approach in the neotropical Erythrinidae fish, Hoplias malabaricus. Karyotipic survey, geographic distribution of cytotypes and cytotaxonomic considerations. Chromosome Res., 8: 603-613.

BERTOLlO, L. A. C., TAKAHASHI, C. S. \& MOREIRAFILHO, O., 1978, Cytotaxonomic considerations on Hoplias lacerdae (Pisces, Erythrinidae). Brazil. J. Genetics, 1: 103-120.

BURGESS, W. E., 1989, An Atlas of Freshwater and Marine Catfishes, a preliminary survey of the Siluriformes. TFH Publications, Neptune, United States, 784p.

CENTOFANTE, L., BERTOLLO, L. A. C., MIYAZAWA, C.S. \& MOREIRA-FILHO, O., 2003, Chromosomal differentiation among allopatric populations of Hyphessobrycon anisitsi (Pisces, Tetragonopterinae). Cytologia, 68: 283-288.

DIAS, A. L. \& FORESTI, F., 1993, Cytogenetic studies on fishes of the family Pimelodidae (Siluroidei). Brazil. J. Genetics, 16: 585-600.

FENOCCHIO, A. S., 1993, Cromossomos supranumerários no gênero Rhamdia (Pisces). Caracterização cromossômica e considerações sobre a evolução cariotípica nos Siluroidei.
PhD Thesis - Universidade de São Paulo, Ribeirão Preto, Brazil.

FENOCCHIO, A. S. \& BERTOLLO, L. A. C., 1992a, Karyotype similarities among Pimelodidae (Pisces, Siluriformes) from the Brazilian Amazon region. Cytobios, 69: 41-46.

FENOCCHIO, A. S. \& BERTOLLO, L. A. C., 1992b, Karyotype, C-bands and NORs of the neotropical siluriform fish Ageneiosus brevifilis and Ageneiosus atronases (Ageneiosidae). Cytobios, 72: 19-22.

FENOCCHIO, A. S., JORGE, L. C., VÊNERE, P. C. \& BERTOLLO, L. A. C., 1993, Karyotypic characterization and nucleolus organizer regions in three species of Doradidae (Pisces, Siluriformes). Brazil. J. Genetics, 16: 1097-1101.

HOWELL, W. M. \& BLACK, D. A., 1980, Controlled silver staining of nucleolus organizer regions with a protective colloidal developer: a 1-step method. Experientia, 36: 1014-1915.

LEVAN, A., FREDGA, K. \& SANDBERG, A. A., 1964, Nomenclature for centromeric position on chromosomes. Hereditas, 52: 201-220.

MOREIRA FILHO, O. M. \& BERTOLLO, L. A. C., 1991, Astyanax scabripinnis (Pisces, Characiformes): a species complex. Brazil. J. Genetics, 14: 331-357.

OLIVEIRA, C., 1991, Estudos citogenéticos e de conteúdo de DNA na família Callichthyidae (Pisces, Siluriformes). $\mathrm{PhD}$ Thesis - Universidade de São Paulo, São Paulo, Brazil.

OLIVEIRA, C., ALMEIDA TOLEDO, L. F., FORESTI, F., BRITSKI, H. A. \& TOLEDO FILHO, S. A., 1988, Chromosome formulae of neotropical fresh water fishes. Brazil. J. Genetics, 11: 577-624.

OLIVEIRA, C., ALMEIDA TOLEDO, L. F. \& TOLEDO FILHO, S. A., 1990, Cytogenetics analysis of three cytotypes of Corydoras nattereri (Pisces, Siluriformes, Callichthyidae). Cytologia, 55: 21-26.

OliveIRA, C., ALMEIDA TOLEDO, L. F., MORI, L. \& TOLEDO FILHO, S. A., 1992, Extensive chromosomal rearrangements and nucleolar DNA content changes in the evolution of the armoured catfishes genus Corydoras (Pisces, Siluriformes, Callichthyidae). J. Fish Biol., 40: 419-431.

OLIVEIRA, C., ALMEIDA TOLEDO, L. F., MORI, L. \& TOLEDO FILHO, S. A., 1993a, Cytogenetic and DNA content studies of armoured catfishes of the genus Corydoras (Pisces, Siluriformes, Callichthyidae) from the southeast coast of Brazil. Brazil. J. Genetics, 16: 617-629.

OLIVEIRA, C., ALMEIDA TOLEDO, L. F., MORI, L. \& TOLEDO FILHO, S. A., 1993b, Cytogenetic and DNA content in six genera of the family Callichthyidae (Pisces, Siluriformes). Caryologia, 46: 171-188.

PINKEL, D., STRAUME, T. \& GRAY, J. W., 1986, Cytogenetic analysis using quantitative, high-sensitivity, fluorescence hybridization. Proc. Natl. Acad. Sci. USA, 83: 2934-2938.

PORTO, J. I. R. \& FELDBERG, E., 1992, Compative cytogenetic study of the armoured catfishes of the genus Hoplosternum (Siluriformes, Callichthyidae). Brazil. J. Genetics, 15: 359-367. 
REIS, R. E., 1998, Anatomy and phylogenetic analysis of the neotropical callichthyid catfishes (Ostariophysi, Siluriformes). Zool. J. Linn. Soc., 124: 105-168.

SUMNER, A. T., 1972, A simple technique for demonstrating centromeric heterochromatin. Exp. Cell Res., 75: 304-306.

TURNER, B. J., DIFFOOT, N. \& RASCH, E. M., 1992, The callichthyid catfish Corydoras aeneus is an unresolved diploid-tetraploid sibling complex. Ichthyol. Explor. Freshwaters, 3: 17-23.

WEITZMAN, S. H., MENEZES, N. A. \& WEITZMAN, M. J., 1988, Phylogenetic biogegraphy of the Glandulocaudini (Teleostei: Characiformes, Characidae) with comments on the distribution of other freshwater fishes in eastern and southeastern Brazil. In: W. R. Heyer \& P. E. Vanzolini (eds.), Proccedings of a workshop on neotropical distribution patterns, Academia Brasileira de Ciências, Rio de Janeiro.

WHITE, T. J., BRUNS, T., LEE, S. \& TAYLOR, L., 1990 Amplification and direct sequencing of fungal ribosomal RNA genes for phylogenetics, pp. 315-322. In: PCR Protocols: a guide to methods and applications. M. A. Innis, D. H. Gelfand, J. J. Sninsky \& T. J. White (eds.), Academic Press, Inc., New York.

WINEMILLER, K. O., 1989, Patterns of variation In life history among South American fishes in seasonal environmentals. Oecologia, 81: 225-241. 